\title{
HUBUNGAN RESPONSE TIME PERAWAT DENGAN KEPUASAN KELUARGA PASIEN DI INSTALANSI GAWAT DARURAT (IGD) RSUD Dr. PIRNGADI MEDAN TAHUN 2016
}

\begin{abstract}
Ns, Marlisa,
ABSTRACT

Family statisfaction is determined by a good response time. The objective of this research is to investigate the correlation between the nurses's response time in giving service and family statisfaction at Emergency Unit of RSUD Dr.Pirngadi Medan This research use th correlational descriptive method. The population of this research consisted of 597 patient. Yhe sample of the research consisted of 42. They were colleted through stopwacth/handphone that have a stopwatch to caculate the response time and questionnsire consisting of 20 questions about family statisfiction of patient.The result of the research show that nurses'response time at Emergency Unit RSUD Dr.Pirngadi Medan was a past's response time.In addition, the family of patients were statisfied with the service at Emergency Unit of RSUD Dr.Pirngadi Medan. There was a corelation between the nurses's response time in giving service and the family statisfaction at Emergency Unit of RSUD Dr. Pirngadi of medan as indicate by the p.value $=0.02$ and the correlation coeficient value $=0.01$
\end{abstract}

\section{Keywords:Response Time, Family Satifactions}

Kepuasan pelanggan ditentukan oleh pelayanan yang salah satunya adalah waktu tanggap (respone time) yang cepat dan penanganan yang tepat. Tujuan penlitian ini adalah untuk melihat gambaran tentang hubungan antara response time perawat dalam memberikan pelayanan dengan kepuasan keluarga pasien di Instalansi Gawat Darurat (IGD) RSUD Dr. Pirngadi Medan. Metode penelitian yang digunakan pada penelitian ini adalah metode dekskriftif korelasi. Populasi yang digunakan dalam penelitian ini adalah 597 pasien. Sampel yang digunakan adalah 42 responden yang dipilih secara Accidental Sampling. Instrumen yang digunakan dalam penelitian ini adalah stopwacth/arloji/Handphone yang mempunyai stopwacth untuk menghitung response time dan kusioner kepuasan keluarga pasien yang terdiri dari 20 pertanyaan.

Hasil penelitian menunjukkan bahwa response time perawat Instalansi Gawat Darurat (IGD) RSUD Dr. Pirngadi Medan adalah response timeyang cepat. Kepuasan pelanggan menunjukkan puas terhadap pelayanan di Instalansi Gawat Darurat (IGD) RSUD Dr. Pirngadi Medan. Ada hubungan antara response time perawat dalam memberikan pelayanan dengan kepuasan keluarga pasien di Instalansi Gawat Darurat (IGD) RSUD Dr. Pirngadi Medan dengan tingkat keeratan rendah ( $\rho$ value 0,02 koefisien korelasi 0.01).

\section{PENDAHULUAN}

Pada saat ini, rumah sakit berkembang sebagai sebuah industri padat karya, padat modal, dan padat teknologi. Disebut demikian karena rumah sakit memamfaatkan Sumber Daya Manusia (SDM) dalam jumlah yang besar dan beragam kualifikasi. Demikian pula, jumlah dana yang digunakan untuk melaksanakan berbagai jenis pelayanan, termasuk pendapatan rumah sakit. Produk umum industri rumah sakit adalah jasa pelayanan kesehatan (Muninjaya, 2012).

Pelayanan kesehatan juga diartikan sebagai sebuah sub sistem pelayanan kesehatan yang tujuan utamanya adalah pelayanan preventif (pencegahan) dan promotif (peningkatan kesehatan) dengan sasaran masyarakat (Notoatmojo, 2012).

Pelayanan keperawatan adalah merupakan sebuah bantuan, dan pelayanan keperawatan ini diberikan karena adanya kelemahan fisik dan mental, adanya keterbatasan pengetahuan serta kurangnya kemampuan menuju kepada kemampuan melaksanakan kegiatan hidup sehari-hari secara mandiri. Pada hakikatnya kegiatan atau pun tindakan keperawatan bersifat membantu (assistive in nature) (Agung, 2010). Pelayanan keperawatan juga diartikan sebagai suatu bentuk pelayanan profesional yang merupakan bagian integral dari pelayanan kesehatan yang didasarkan pada ilmu dan kiat keperawatan, berbentuk pelayanan biopsikososial dan spiritual yang komprehensif, ditujukan kepada individu, keluarga dan masyarakat baik sakit maupun sehat yang mencakup seluruh proses kehidupan manusia (Hidayat, 2008).

Pelayanandalam kegawatdaruratan memerlukan penanganan secara terpadu dari multi disiplin profesi termasuk pelayanan keperawatan yang merupakan bagian integral yang mengutamakan akses pelayanan kesehatan bagi korban dengan tujuan mencegah dan mengurangi angka kesakitan, kecacatan dan kematian (Haryatun, 2008).

Keperawatan merupakan ujung tombak dari pelayanan di rumah sakit, dimana selama dua puluh 
empat jam perawatlah yang selalu berada didekat pasien sehingga perawat memegang peran cukup dominan dalam rangka memberi kepuasan kepada pasien (Mustofa, 2008).

Kepuasan adalah tingkat perasaan seseorang setelah membandingkan kinerja atau hasil yang dirasakannya dengan harapannya. Tingkat kepuasan merupakan fungsi dari perbedaan antara kinerja yang dirasakan dengan harapan. Apabila kinerja dibawah harapan, maka pelanggan akan sangat kecewa, bila sesuai harapan, maka pelanggan akan sangat puas. Sedangkan bila kinerja melebihi harapan pelanggan akan sangat puas. Di samping itu harapan pelanggan dapat dibentuk oleh pengalaman masa lampau, komentar dari kerabatnya serta janji dan informasi dari berbagai media. Pelanggan yang puas akan setia lebih lama, kurang sensitif terhadap harga dan memberi komentar yang baik tentang tersebut (Aditama, 2008).

Instalasi Gawat Darurat (IGD) adalah suatu unit integral dalam satu rumah sakit dimana semua pengalaman pasien yang pernah datang ke Instalansi Gawat Darurat (IGD) tersebut akan dapat menjadi pengaruh yang besar bagi masyarakat tentang bagaimana gambaran rumah sakit itu sebenarnya. Fungsinya adalah untuk menerima, menstabilkan dan mengatur pasien yang menunjukkan gejala yang bervariasi dan gawat serta juga kondisi-kondisi yang sifatnya tidak gawat. Unit gawat darurat juga menyediakan sarana penerimaan untuk penatalaksanaan pasien dalam keadaan bencana, hal ini merupakan bagian dari perannya di dalam membantu keadaan bencana yang terjadi di tiap daerah (Agung, 2014).

Sebagai pintu terdepan rumah sakit, Instalansi Gawat Darurat (IGD) memegang peran yang sangat penting. Instalansi Gawat Darurat (IGD) harus bisa memberikan pertolongan yang cepat dan tepat untuk keselamatan pasien (Wilde, 2009).

Kecepatan dan ketepatan pertolongan yang diberikan pada pasien yang datang ke Instalansi Gawat Darurat (IGD) memerlukan standar sesuai dengan kompetensi dan kemampuannya sehingga dapat menjamin suatu penanganan gawat darurat dengan response time perawat yang cepat dan penanganan yang tepat (Kemenkes RI, 2009).

Response time merupakan kecepatan dalam penanganan pasien, dihitung sejak pasien datang sampai dilakukan penaganan (Suhartati, 2011). Waktu tanggap yang baik bagi pasien yaitu $\leq 5$ menit ( Keputusan Menteri Kesehatan Republik Indonesia, 2009).

Response time penanganan dapat dihitung dengan hitungan menit dan sangat dipengaruhi oleh berbagai hal, baik mengenai jumlah tenaga maupun komponen-komponen lain yang mendukung seperti layanan laboratorium, radiologi, farmasi dan administrasi. Waktu tanggap dikatakan tepat waktu atau tidak terlambat apabila waktu ynag diperlukan tidak melebihi waku rata-rata standar yang ada (Haryatun dan Sudaryanto, 2008).
Berdasarkan data kunjungan pasien ke Instalansi Gawat Darurat (IGD) diseluruh Indonesia mencapai 4.4 02.205 (13,3\% dari total seluruh kunjungan di Rumah Sakit Umum (RSU) dengan jumlah kunjungan 12\% dari kunjungan Instalansi Gawat Darurat (IGD) berasal dari rujukan dengan jumlah Rumah Sakit Umum (RSU) 1.033 Rumah Sakit Umum (RSU) dari 1.319 rumah sakit yang ada. Jumlah yang signifikan ini kemudian memerlukan perhatian yang cukup besar dengan pelayanan pasien gawat darurat (Kepmenkes, 2009).

Hasil penelitian Widodo (2014) tentang kepuasan pelanggan terhadap response time perawat di salah satu Instalansi Gawat Darurat (IGD) di sebuah rumah sakit menjelaskan bahwa dari 95 orang responden terdapat 4 pasien kategori "rendah/kurang puas", dan 8 pasien kategori "sedang/cukup puas", dan 83 pasien kategori "tinggi/puas".

Hasil penelitian Dewi (2015) tentang kepuasan keluarga terhadap response time perawat Instalansi Gawat Darurat (IGD) di salah satu rumah sakit di Manado menjelaskan bahwa dari 30 orang responden, terdapat 6 keluarga pasien kategori "kurang puas", dan 24 orang keluarga pasien kategori "puas".

Berdasarkan survei pendahuluan yang peneliti lakukan di RSUD Dr. Pirngadi Medan pada tanggal 22 Januari 2016, dengan melakukan wawancara terhadap 3 responden dengan mengajukan pertanyaan "Apakah anda puas dengan pelayanan yang diberikan oleh perawat kepada keluarga anda?" hasilnya 1 responden mengatakan kurang puas, dan 2 responden mengatakan puas dengan pelayanan yang diberikan perawat. Dari survey yang dilakukan didapat juga data pasien yang berkunjung keInstalansi Gawat Darurat (IGD)dari tahun ke tahun semakin meningkat. Pada tahun 2013 ada sebanyak 5879 pasien yang berkunjung, dan pada tahun 2014pasien yang berkunjung sebanyak 6227pasien dan pada tahun 2015 terjadi juga peningkatan jumlah pasien yang berkunjung yaitu sebanyak 7164 pasien.

Berdasarkan latar belakang tersebut, maka peneliti tertarik untuk meneliti tentang hubungan response time perawat dengan tingkat kepuasan keluarga pasien di Instalansi Gawat Darurat (IGD) RSUD Dr.Pirngadi Medan.

\section{METODE}

Penelitian ini menggunakan desain penelitian analitik observasi dengan studi korelasional. Studi korelasional pada hakikatya merupakan penelitian atau penelaahan hubungan antara dua variabel pada suatu situasi atau sekelompok subjek (Notoatmodjo, 2012).

Rancangan penelitian yang akan digunakan adalah pendekatan cross sectional.

Peneliti menentukan populasi pada penelitian ini menggunakan rata-rata jumlah pasien Instalansi GawatDarurat (IGD) perbulan dalam periode tahun 2015 di Instalansi GawatDarurat (IGD) RSUD Dr.Pirngadi Medan yaitu sekitar 597 pasien/bulan. 
Besar sampel dalam penelitian ini akan diketahui melalui rumus Slovin (Nursalam, 2009) sebagai berikut :

$$
\begin{aligned}
& n=\frac{N}{1+N(d)^{2}} \\
& n=\frac{597}{1+597(0,0225)}
\end{aligned}
$$

$n=41,364$ dibulatkanmenjadi 42 responden

Keterangan :

$\mathrm{N}$ : Besar populasi

n : Jumlah sampel

d : Tingkat ketepatan yang diinginkan (15 $\%)$

Dalam penentuan sampel, peneliti juga menentukan kriteria inklusi sebagai berikut :

1. Keluarga pasien Instalansi Gawat Darurat (IGD) atau pendamping pasien yang bersedia menjadi responden.

2. Keluarga pasien Instalansi Gawat Darurat (IGD) yang mampu membaca

\begin{tabular}{|c|c|c|c|c|c|c|c|c|}
\hline \multirow{3}{*}{$\begin{array}{c}\text { isponse } \\
\text { Time }\end{array}$} & \multicolumn{6}{|c|}{ Kepuasan Keluarga Pasien } & & \\
\hline & \multicolumn{2}{|c|}{ Tinggi } & \multicolumn{2}{|c|}{ Sedang } & \multicolumn{2}{|c|}{ Rendah } & \multicolumn{2}{|c|}{ Total } \\
\hline & $\mathrm{F}$ & $\%$ & $\mathrm{f}$ & $\%$ & $\mathrm{f}$ & $\%$ & $\mathrm{f}$ & $\%$ \\
\hline \multirow{5}{*}{ Cepat } & \multirow{5}{*}{24} & ;7, & \multirow{5}{*}{4} & 9 & \multirow{5}{*}{2} & 4 & \multirow{5}{*}{30} & \multirow{5}{*}{$\begin{array}{r}71 \\
4 \\
\%\end{array}$} \\
\hline & & 1 & & , & & ' & & \\
\hline & & 4 & & 5 & & 6 & & \\
\hline & & & & 2 & & & & \\
\hline & & $\%$ & & $\%$ & & $\%$ & & \\
\hline \multirow{5}{*}{ Lambat } & \multirow{5}{*}{3} & & \multirow{5}{*}{6} & 1 & & 7 & \multirow{5}{*}{12} & \multirow{5}{*}{$\begin{array}{c}28 \\
6 \\
\%\end{array}$} \\
\hline & & 7,1 & & 4 & & , & & \\
\hline & & 4 & & 3 & 3 & $\begin{array}{l}1 \\
4\end{array}$ & & \\
\hline & & $\%$ & & 0 & & & & \\
\hline & & & & $\%$ & & $\%$ & & \\
\hline \multirow{6}{*}{ Total } & \multirow{6}{*}{27} & & \multirow{6}{*}{10} & & & 1 & \multirow{6}{*}{42} & \\
\hline & & 34 & & 2 & \multirow{5}{*}{5} & 1 & & \\
\hline & & 2 & & 3 & & , & & 10 \\
\hline & & 8 & & , & & 9 & & 0 \\
\hline & & & & 3 & & 0 & & $\%$ \\
\hline & & $\%$ & & $\%$ & & & & \\
\hline
\end{tabular}

3. Keluarga pasien Instalansi Gawat Darurat (IGD)

yang mengantar pasien atau mendampingi pasien dari awal dan menunggui pasien hingga pasien selesai ditangani.

\section{Hasil Penelitian}

Dari hasil penelitian yang dilakukan pada tanggal 15 Juli sampai tanggal 25 Juli dengan judul "Hubungan Response Time Perawat Dengan Kepuasan Keluarga Pasien di Instalansi Gawat Darurat (IGD) RSUD Dr. Pirngadi Medan Tahun 2016" diperoleh data yang sudah diolah dan disajikan dalam bentuk tabel sebagai berikut :

\begin{tabular}{lcc}
\hline Kepuasan Keluarga & $\mathrm{N}$ & $\%$ \\
\hline Kepuasan Tinggi & 27 & $64,3 \%$ \\
Kepuasan Sedang & 10 & $23,8 \%$ \\
Kepuasan Rendah & 5 & $11,9 \%$ \\
\hline Total & & \\
\hline
\end{tabular}

Tabel Distribusi frekuensi berdasarkan Response Time perawat gawat darurat di Instalansi Gawat Darurat (IGD) RSUD Dr. Pirngadi Medan Tahun 2016

Berdasarkan tabel di atas dapat diambil kesimpulan bahwa response time perawat dalam memberikan pelayanan di Instalansi Gawat Darurat (IGD) RSUD Pirngadi Medan Tahun 2016 cepat. Dimana jumlah response time yang lambat sebanyak 12 orang $(28,6 \%)$ danresponse time yang cepat sejumlah 30 orang $(71,4 \%)$.

Tabel Distribusi Frekuensi berdasarkan kepuasan keluarga pasien gawat darurat di Instalansi Gawat Darurat (IGD) RSUD Dr. Pirngdi Medan Tahun 2016.

Berdasarkan tabel di atas dapat diambil kesimpulan bahwa mayoritas pelanggan di Instalansi Gawat Darurat (IGD) RSUD Dr. Pirngadi Medam memiliki kategori tingkat kepuasan tinggi 27 responden $(64,3 \%)$, kategori tingkat kepuasan sedang ada 10 responden $(23,8 \%)$ dan 5 responden $(11,9 \%)$ memiliki kategori tingkat kepuasan rendah.

Tabel Distribusi frekuensi berdasarkan Response time dan Kepuasan Keluarga Di Instalasi Gawat Daruat (IGD) RSUD Dr. Pirngadi Medan.

\begin{tabular}{lll}
\hline Response time & $\mathrm{N}$ & $\%$ \\
\hline
\end{tabular}

Response time cepat $\quad 30 \quad 71,4 \%$

Response time lambat $\quad 12 \quad 28,6 \%$

\begin{tabular}{lll}
\hline Total & 42 & $100,00 \%$
\end{tabular}

Tabel di atas menunjukan bahwa kepuasan keluarga pasien kategori tinggi dengan response time yang cepat sebanyak 24 responden $(57,14 \%)$, dan kepuasan

keluarga dengan kategori sedang dengan response time yang cepat sebanyak 3 responden $(7,14 \%)$, dan kepuasan keluarga dengan kategori rendah dengan response time yang cepat sebanyak 2 responden $(4,76 \%)$. 
Berdasarkan hasil uji statistik chi-squaremaka didapatkan nilai $\rho$ yang menunjukkan ada hubungan yang bermakna antara response time dengan kepuasan keluarga pasien dimana $\rho<0,05$ yaitu 0,02 .

Berdasarkan hasil uji statistik menunjukkan bahwa ada hubungann antara response time dengan kepuasan keluarga pasien. Dimana pada response time yang lambat (> 5 menit) dari 42 responden ada 6 responden yang memiliki kepuasan kategori sedang dan 3 responden memiliki kepuasan kategori rendah terhadap pelayanan yang diterima dari petugas kesehatan.

\section{A. Pembahasan}

\section{Response Time}

Hasil distribusi frekuensi response time perawat dalam memberikan pelayanan di Instalansi Gawat Darurat (IGD) RSUD Dr.Pirngadi Medan menunjukkan response time cepat sebanyak 30 responden atau sekitar $71,4 \%$ responden. Dengan hasil rata-rata response time Instalansi Gawa Darurat (IGD) RSUD Dr. Pirngadi Medan yaitu 2,12 menit.

Ketersediaan petugas triase juga sesuai dengan penelitian Eko widodo, bahwa penempatan staf perawat sangat mempengaruhi response time perawat, namun menurut mereka tidak terdapat hubungan yang bermakna antara pola penempatan staf dengan ketepatan waktu tanggap penanganan kasus di Instalansi Gawat Darurat (IGD) RSUD Dr.Pirngadi Medan.

Langkah selanjutnya adalah dengan memenuhi sarana dan prasarana. Selain alat medis yang memadai, untuk memberikan kesan bahwa pelayanan yang cepat diperlukan jumlah streecher/tempat tidur pasien yang cukup.

Kegiatan memenuhi kebutuhan tenaga di Instalansi Gawat Darurat (IGD) dan sarana prasarana juga perlu didukung adanya sistem menejemen yang baik dalam mencapai Standar Pelayanan Minimal (SPM). Faktor sistem menejemen Instalansi Gawat Darurat (IGD) yang baik dalam menagani setiap pasien gawat darurat juga ditunjukkan melalui motto "kepentingan penderita adalah yang utama". Sistem menejemen yang baik ini mendukung Kepmenkes RI No.856 tahu 2009 tengtang standar Instalansi Gawat Darurat (IGD) Rumah Sakit yang menyatakan bahwa kecepatan dan ketepatan pertolongan yang diberikan pada pasien yang datang ke Instalansi Gawat Darurat (IGD) memberikan standar sesuai dengan kompetensi dan kemampuanya sehingga dapat menjamin suatu penanganan gawat darurat dengan response time yang cepat dan penanganan yang tepat. Hal ni dapat dicapai dengan meningkatkan sarana, prasarana, Sumber Daya Manusia (SDM) dan menejemen Instalansi Gawat Darurat (IGD) rumah sakit sesuai standar.

\section{Kepuasan Keluarga Pasien}

Hasil distribusi frekuensi kepuasan keluarga pasien di Instalansi Gawat Darurat(IGD) RSUD Dr.Pirngadi Medan menunjukan kategori kepuasan tinggi sebanyak 30 orang atau 64,2\%.

Peneliti menyimpulkan bahwa kualitas Sumber Daya Manusia (SDM) di Instalansi Gawat Darurat (IGD) RSUD Pirngadi Medan memberikan mamfaat yang sangat besar bagi kepuasan pelanggan. Hal ini dibuktikan dengan penilaian tertinggi tentang sikap perawat dari aspek lain yang memberikan penilaian tinggi pula pada kemampuan dan sikap profesional petugas Instalansi Gawat Darurat (IGD) dibandingkan dengan penilain terhadap kondisi ruang maupun fasilitas yang terdapat Instlansi Gawat Darurat (IGD). Hasil penelitian juga menunjukkan responsiviness perawat mendapatkan penilaian yang tinggi. Peneliti hannya meneliti dua variabel yaitu hannya sebatas response time dan kepuasan keluarga pasien. Oleh karena itu penliti menggunakan metode servqual dimana pasien atau keluarga pasien mengisi kusioner yang dibagikan oleh peneliti berdasarkan atas apa yang dirasakan setelah selesai di berikan pelayanan.

\section{Hubungan Response Time Perawat Dalam Memberikan Pelayanan Dengan Kepuasan Keluarga di Instalansi Gawat Darurat (IGD).}

Uji statistik mengenai hubungan response time perawat dalam memberikan pelayanan dengan kepuasan keluarga pasien di Instalansi Gawat Darurat (IGD) RSUD Dr.Pirngadi Medan dengan menggunakan korelasi chi-square diperoleh hasil $\rho=0,02$ yaitu ada hubungan antara response time perawat dalam memberikan pelayanan dengan kepuasan keluarga pasien di IGD RSUD Dr. Pirngadi Medan dengan tingkat korelasi rendah .

Upaya memberikan pelayanan agar bisa memberikan kepuasan bagi keluarga maupun pasienkhususnya pelayanan gaawat darurat dapat dinilai dari kemampuan perawat dalam hal responsiviness(cepat tanggap), reliability (pelayanan tepat waktu), assurance (sikap dalam mmberikan pelayanan), empathy (kepedulian dan perhatian dalam memerikan pelayanan) dan tangible (mutu jasa pelayaanan) dariperawat kepada pasien (Muninjaya, 2012).

Bedasarkan teori tersebut responsiveness memberikan dampak bagi kepuasan pelanggan. Responsiveness dalam pelayanan di Instalansi Gawat Darurat (IGD) mencakup dua hal yatu response time pada saat pasien datang dan waktu pelayanan sampai selesai proses pelayanan ( Hariatun dan Sudaryanto, 2008).

Mengenai tingkat korelasi yang rendah dapat disebabkan oleh bebrapa faktor diantaranya karateristik pasien yang datang ke Instalansi Gawat Darurat (IGD) terutama saat sore dan malam hari tidak semua merupakan kasus true emergency yang membutuhkan penanganan segera sehingga kecepatan bukan merupakan hal utama yang dibutuhkan, namun 
keramahan dan kemampuan profesianal petugas di Instalansi Gawat Darurat (IGD) dalam memberikan pelayanan dan kesempatan untuk berinteraksi/ berdiskusi menjadi faktor yang diharapkan pasien. Faktor lain yang tidak bisa dikesampingkan adalah budaya masyarakat. Mayoritas pasien di RSUD Dr Pirngadi Medan adalah masyarakat yang memiliki adat istiadat yang lebih mengutamakan keramahan, kesopanan, daripada kecepatan, terlebih apabila kecepatan yang ditunjukkan dalam melayani memberikan kesan tergesa-gesa tidak teliti dan kurang peduli terhadap keluhan pasien. Kesimpulan ini juga sesuai dengan pendapat Eko Widodo (2014) yang menyatakan faktor-faktor yang mempengaruh keluhan pasien yaitu faktor psikologis, demogarafi dan faktor geografi.

\section{KESIMPULAN}

Kesimpulan penelitian tentang hubungan response time perawat dalam memberikan pelayanan dengan kepuasan pelanggan di Instalansi Gawat Darurat (IGD) RSUD Dr. Pirngadi Medan :

1. Response time perawat dalam memberikan pelayanan di IGD memiliki kategori response time cepat $(71,4 \%)$

2. Kepuasan pelanggan Instalansi Gawat Darurat (IGD) didapatkan hasil kategori kepuasan tinggi yaitu $(64,2 \%)$

3. Ada hubungan response time perawat dalam memberikan pelayanan dengan kepuasan keluarga pasien di Instalansi Gawat Darurat (IGD) dengan $\rho$ values 0,02 .

\section{SARAN}

Berdasarkan kesimpulan di atas demi perbaikan dan kemajuan dalam pelayanan di Instalansi Gawat Darurat (IGD) RSUD Dr. Pirngadi Medan disampaikan saran sebagai berikut :

1. Diharapkan bagi petugas Instalansi Gawat Darurat (IGD) hendaknya mengetahui bahwa kualitas pelayanan perawat baik responsiveness, empathy, reliabilithy maupun assurance dapat membuat kepuasan pelaggan di Instalansi Gawat Darurat (IGD) terjaga pada tingkat tinggi.

2. Manajemen rumah sakit sudah baik, namun hendaknya ditingkatkan lagi dalam memilah pasien true emergency dan false emergency dengan adanya klinik 24 jam sehingga tingkat signifikasi response time dengan kepuasan pelanggan akan lebih jelas.

3. Ketersediaan Sumber Daya Manusia (SDM) dan pemenuhan sarana yang lebih baik memberikan kecepatan dan ketepatan dalam pelayananan

4. Survey tingkat kepuasan pelanggan hendaknya tidak dilihat dengan satu variabel/elemen saja tetapi dengan 5 elemen yang mempengaruhi kepuasan pelanggan. 